COMPETITOR: Jurnal Pendidikan Kepelatihan Olahraga

Volume 13 Number 1 Year 2021

e-ISSN: 2657-0734 \& p-ISSN: 2085-5389

This work is licensed under a Creative Commons Attribution 4.0 International License

\title{
Implementation of Behaviorism Theory-based Training Learning Model in Physical Education in Class VII Junior High School Football Game Materials
}

\author{
Pinton Setya Mustafa \\ Faculty of Tarbiyah and Teacher Training /Mataram State Islamic University/ \\ West Nusa Tenggara/Indonesia \\ J1. Pendidikan No.35, Dasan Agung Baru, Kec. Selaparang, Mataram City, West Nusa Tenggara. 83125 \\ pintonsetyamustafa@uinmataram.ac.id
}

Received: December 14, 2020; Reviewed: January 04, 2021; Accepted: February 23, 2021;

Published: February 28, 2021

\begin{abstract}
This article aims to provide information about learning based on behaviorism learning theory through a drill learning model in football game material in grade VII Junior High School. Behaviorism learning theory, which has the principle of providing a stimulus that results in a response. The stimulus is given by the teacher in the form of material that needs to be done by students, resulting in students responding by doing assignments from the material. Physical education, sports, and health (PESH) learning activities involve moving activities to achieve competence. The game of football is one of the materials used in learning PESH movements. The principle of learning PESH is to involve students to move happily. The drill learning model is an alternative that can be used in soccer learning for seventh-grade students of junior high school. The exercise learning model is repeating movements in sports techniques that have been compiled by the teacher. In conclusion, with a variety of exercise learning models, students can learn PESH material to achieve better and more active sports movements and feel happy. Teachers need to innovate continuously to design learning models that are following the characteristics of students.
\end{abstract}

Keywords: Learning Theory; Behaviorism; Practice; Physical Education; Football Game.

\section{INTRODUCTION}

Learning is a very vital human activity and will continuously be carried out as long as the human is still alive. Humans are not able to live as humans if they are not educated or taught by other humans. The newborn human has brought some instincts or instincts and the potentials needed for his survival. However, these instincts and potentials will not develop properly without outside influence, namely the intervention of other humans. Learning is an internal process that cannot be seen in real life in a person who is experiencing the learning process. Thus, with the existence of learning activities, individuals gain knowledge or changes in behavior from the learning outcomes. So that it can be interpreted that learning is a process of changing behavior due to experience, 
Implementation of Behaviorism Theory-based Training Learning Model in Physical Education in Class VII Junior High School

Football Game Materials

Pinton Setya Mustafa

pintonsetyamustafa@uinmataram.ac.id

which is relatively permanent, towards good, positive-qualitative changes which also mechanizes values and norms (Suyono \& Hariyanto, 2012, p.13). With the term learning, learning will appear.

Learning is a learning process that is repeated and causes changes in behavior that are conscious and tend to be permanent (Thobroni, 2015, p.19). Learning requires a conscious process to change relatively permanent behavior. In this process, information is recalled which is then stored in memory and cognitive organization. Furthermore, these skills are practically manifested in the activeness of students in responding and reacting to events. Learning can be defined as activities designed by educators to help someone learn new abilities and or values in a systematic process through the stages of design, implementation, and evaluation in the context of teaching and learning by taking into account the talents, interests, and pedagogic and psychological development of students. (Munir, 2012, p. 96). Then the role of the teacher in the learning process is to encourage, guide, and provide learning facilities for students to achieve goals (Magdalena, Hidayah, \& Astuti, 2020, p.383). Thus a teacher in carrying out learning is based on learning theory from psychology. One of the most frequently used schools of learning theory from psychology is behaviorism.

The flow of behaviorism explains that learning is an activity carried out by learning managers to create environmental conditions that allow the learning process to occur (Munir, 2012, p.97). Behaviorism learning is molecular, meaning that it emphasizes the elements of learning, seeing that individual life consists of elements such as molecules (Suyono \& Hariyanto, 2012, p.58). In a learning mechanism based on behaviorism, the input provided in the form of a stimulus/stimulus provided by the educator/teacher will produce an output in the form of a response to the results of the learner's response to the stimulus given (Restian, 2015, p.119). Thus the concept of behaviorism learning emphasizes that students will learn because of a stimulus from the teacher or the environment, so if there is no stimulus, students will be passive or not learn. This learning theory gave birth to one of the teaching styles, namely practice or what was called a drill. Where the training stimulus provider is the teacher so that the student's response will learn by doing the exercises given by the teacher.

The drill model is generally used to acquire dexterity or skills from what has been learned and to acquire motor skills (Mustafa \& Sugiharto, 2020, p.214; Sudjana, 2010, 
Implementation of Behaviorism Theory-based Training Learning Model in Physical Education in Class VII Junior High School

Football Game Materials

Pinton Setya Mustafa

pintonsetyamustafa@uinmataram.ac.id

p.87). Practices and exercises are generally used for the continuous skills training learning process (Munir, 2012, p.69). Learners will do the exercises repeatedly according to the appropriate procedure. Practical exercises that are easy to do and carry out regularly foster children in increasing their mastery of these skills, maybe even learners can have these skills perfectly (Mustafa, Winarno, \& Asim, 2016, p. 173; Roestiyah, 2008, p. 125). Besides, according to Djamarah \& Zain (2010, p. 88) drill is a good way of learning to instill certain habits, as well as a means of maintaining good habits. So that by doing the exercises repeatedly, learners will be able to achieve the expected skills. One of the subjects at school that emphasizes skills in Physical Education, Sports, and Health (PESH).

Physical education is a curriculum of integral education with a teaching model designed to provide students with authentic experiences that are thorough and enjoyable and that contribute to being physically active throughout life (Mustafa, Winarno, \& Supriyadi, 2019, p.1364; Siedentop, Hastie, \& Mars, 2011, p.1). The goals of physical education are classified into three psychomotor, cognitive, and affective domains (Mustafa \& Dwiyogo, 2020, p.435; Shimon, 2011, p.51). In (PESH), the main goal must be following the educational goals which take an emphasis on the formation of student health by habituating the quantity and quality of movement in learning (Mustafa \& Winarno, 2020, p.88; Roesdiyanto, 2017, p.615). Thus in learning (PESH) emphasizes movement or physical skills. So that the drill learning model is harmoniously used in PESH. The learning model is following PP RI No. 19 of 2005 concerning National Education Standards Article 19 paragraph 1, namely the learning process in educational units is held interactively, inspiring, fun, challenging, motivating students to actively participate, and providing sufficient space for the initiative, creativity, and independence following the talents, interests, and physical and psychological development of students. Thus, one of the learning models in PESH that emphasizes skills can use drills or exercises. However, before determining the selection of the learning model, you must also look at the Core Competencies (CC) and Basic Competencies (BC) of the 2013 curriculum that were achieved in (PESH) lessons:

Tabel 1.

Basic Competencies of Class VII SMP/MTs

Basic competencies

Basic competencies

3.1 Understand specific moves in various 4.1 Practicing specific moves in various simple and/or traditional big ball games *) simple and/or traditional big ball games

(Source: Permendikbud No. 24 Tahun 2016 tentang Kompetensi Inti dan Kompetensi Dasar Pelajaran pada Kurikulum 2013) 
Implementation of Behaviorism Theory-based Training Learning Model in Physical Education in Class VII Junior High School

Football Game Materials

Pinton Setya Mustafa

pintonsetyamustafa@uinmataram.ac.id

Based on KD 3.1 and 4.1 from Table 1, the goal of competence can be achieved, one of which is football material. In the football material, it can also be specified that the content of learning about basic football techniques with simple games. The results showed that teachers often use training styles to teach motor skills to students, and also often ignore feedback (Syrmpas \& Digelidis, 2014, p. 56). Therefore, a discussion of the article will be presented with the application of the behaviorism theory-based training learning model in physical education. In the discussion of the application of the training learning model, it is only illustrated in the VII grade PESH subjects with football material based on BC 3.1 and 4.1 in the 2013 curriculum.

\section{METHOD}

This study uses a literature study approach, which collects reference sources about the training learning model that is based on behavioral learning theory in the context of physical education with football game material at the seventh grade level of junior high school. The procedures for this research include: (1) the preparation stage, (2) the implementation stage, and (3) writing down the findings. The preparation stage is to determine the research topic that will be sought for reference sources. The implementation stage is collecting relevant references on the research topic and then describing them briefly. The final stage is to write down the findings to get a common thread from the research topic. Data collection is obtained from a collection of reference books and relevant journal articles related to behaviorism learning theory, learning models, and exercises. Data analysis used a qualitative approach with the stages of data preparation and organization, data exploration, identifying data, describing data, representing findings, and then formulating conclusions (Creswell, 2012, p.261). The final result of this research is an illustration of the exercise learning model on football material for class VII SMP from the study of behaviorism learning theory.

\section{RESULTS AND DISCUSSION}

Behaviorism Learning Theory Before knowing the concept of behaviorism learning theory, it is necessary to understand the meaning of learning. Learning is an activity or a process to acquire knowledge, improve skills, improve behavior, attitudes, and strengthen personality (Suyono \& Hariyanto, 2012, p.9). Besides, learning is a processing activity 
Implementation of Behaviorism Theory-based Training Learning Model in Physical Education in Class VII Junior High School

Football Game Materials

Pinton Setya Mustafa

pintonsetyamustafa@uinmataram.ac.id

and is a very fundamental element in the implementation of the type and level of education, this means that the success of achieving educational goals is highly dependent on the success of the learning process of students in schools and their surroundings (Haris \& Jihad, 2010, p.1). Learning is a form of change experienced by students in terms of their ability to behave in new ways as a result of the interaction between stimulus and response (Budiningsih, 2005, p.20). Besides, learning is a process that must be carried out by students and is characterized by changes in cognitive, affective, and psychomotor aspects (Dimyati, 2016, p.2). Learning is a relatively long-lasting observed behavior change as a result of experience and environment (Hitipeuw, 2009, p.13). Then the learning can be defined as a relatively permanent influence on behavior and knowledge, as well as thinking skills acquired through experience (Santrock, 2012, p.301). Thus it can be said that learning is a process of changing behavior in terms of knowledge, skills, and attitudes which are relatively permanent as a result of training and experience as well as environmental influences. So learning is a process, not a result, the process is done through training or from personal experience and the influence of environmental conditions. The result of learning is a change in behavior in the form of cognitive, affective, or psychomotor. Behavioral psychology views learning as the ability to perform new behaviors that focus on a stimulus-response approach to learning (Richey, Klein, \& Tracey, 2011, p.52). Actions of learning can be carried out by the researcher or, in the application of the situation, by the facilitator, teacher, or learning material. In this learning situation, there is an attempt to create conditions that allow the learner to exhibit the desired behavior and perform it over some time. According to Desmita $(2009$, p.44), behavioristic learning theory is a learning theory to understand human behavior that uses objective, mechanistic, and materialistic approaches, so that behavior changes in a person can be done through conditioning efforts. The flow of behaviorism emphasizes the need for observable behavior. There are several characteristics of this family of theories, namely: (1) prioritizing small elements or parts, (2) being mechanistic, (3) emphasizing the role of the environment, (4) emphasizing the formation of responses, (5) emphasizing the importance of training ( Suyono \& Hariyanto, 2012, p.58). The environment is conditioned as a stimulus in the form of tasks and habituation to bring up discipline which will be responded to by students step by step and followed by feedback which will function as continuous reinforcement so that it is believed that it will be able to change 
Implementation of Behaviorism Theory-based Training Learning Model in Physical Education in Class VII Junior High School

Football Game Materials

Pinton Setya Mustafa

pintonsetyamustafa@uinmataram.ac.id

the learning behavior of students to achieve/master certain competencies (Munir, 2012, p.97). Restian (2015, p.119) argues that there are three important concepts in the psychology of behaviorism, including (1) stimulus, (2) response, (3) reinforcement. The stimulus is whatever the teacher gives to students, while the response is the reaction or response of students to the stimulus provided by the teacher. Then reinforcement is a form of stimulus that is important to be given, added, subtracted, or removed to allow a response (Budiningsih, 2005, p. 20). The statement from DiVesta \& Thompson (1979, p.11) the concept of learning behaviorism in a simple description is as follows.

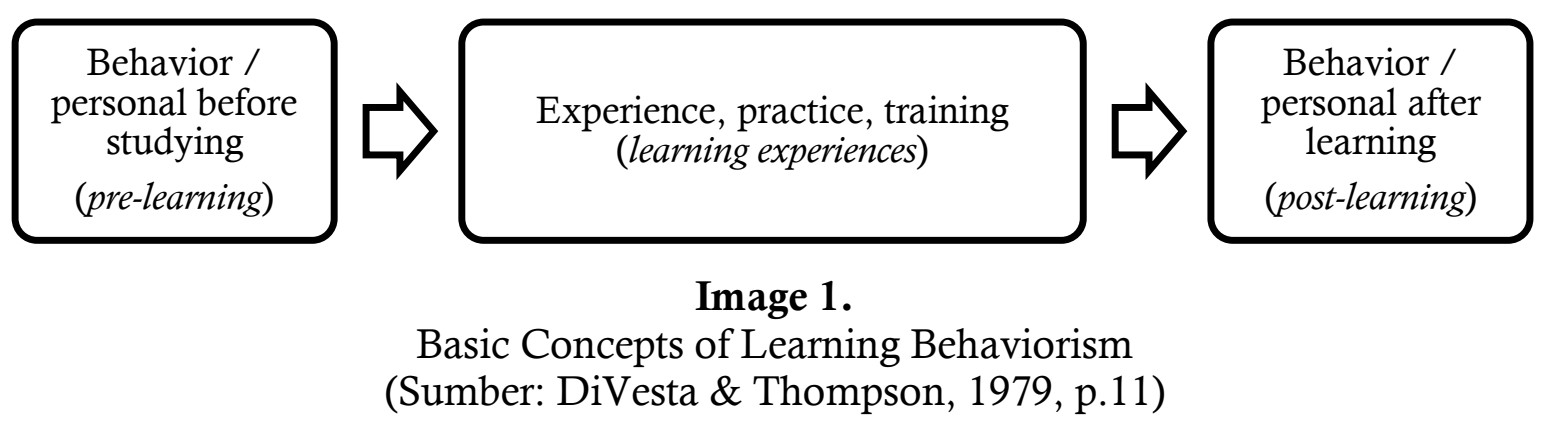

Thus it can be concluded that behaviorism learning theory is the result of learning behavior due to the provision of stimuli from both the teacher and the environment which results in student responses to learning. So in behavior learning theory students tend to passively follow the stimulus provided by the teacher in carrying out learning activities. The behaviorist learning theory that is often based on learning includes (1) Thorndike's connectionism, (2) Pavlov's classical conditioning, and (3) Skinner's operant conditioning (Restian, 2015, pp.122-124). Connectionism gives birth to laws, including: (1) law of effect, namely the response effect is influenced by the strength and weakness of the response stimulus relationship, (2) law of readiness, which is to encourage individuals to do or not, (3) law of exercise is strong and weak learning outcomes because of practice. Then classical conditioning is the creation of new reflexes by bringing in the stimulus before the reflex occurs. Furthermore, in operant conditioning, the behavior is formed by the consequences caused by the behavior itself. From the three learning theories of behaviorism that have been expressed by the figures above, it can be said that learning outcomes are formed from stimuli and responses. The stimulus can be engineered in such a way so that the response is as expected. So when applied in learning, teachers can use various ways so that students want to learn so that the results 
Implementation of Behaviorism Theory-based Training Learning Model in Physical Education in Class VII Junior High School

Football Game Materials

Pinton Setya Mustafa

pintonsetyamustafa@uinmataram.ac.id

can be observed. Learning objectives according to behaviorism theory emphasize the addition of knowledge, while learning is a "mimetic" activity, which requires students to reexamine the knowledge that has been learned in the form of reports, quizzes, or tests (Budiningsih, 2005, p. 28). So learning and evaluation emphasize the results, that is, if students have done the truth of the stimulus provided by the teacher, then the students are considered learning or the learning objectives have been achieved. As for the opinion of Suyono \& Hariyanto (2012, p.71) educational psychology experts agree that learning according to the concept of behaviorism takes place in three main steps, namely: (1) the acquisition stage, namely the stage of acquiring knowledge, meaning that students learn about new information; (2) The retention stage, in this stage new information or skills that have been learned, are then put into practice so that students can remember them for a certain period or it is called the storage stage; (3) The transfer stage, in this stage the ideas or information that have been stored in memory are reused or transferred in new situations (transferring in new learning). Meanwhile, according to Budiningsih (2005, p.29), in general, the learning steps that are based on the behavior theory include: (1) Determining learning objectives; (2) Analyzing the existing classroom environment including identifying students' entry behavior; (3) Determine the subject matter; (4) Breaking the subject matter into small sections, covering the subject, sub-topics, topics, and so on; (5) Presenting subject matter; (6) Providing stimuli, in the form of questions both oral and written, tests/quizzes, exercises, or assignments; (7) Observing and assessing the responses given by students; (8) Provide reinforcement (positive reinforcement or negative reinforcement), or punishment; (9) Providing a new stimulus; (10) Observing and assessing the responses given by students. According to Thobroni (2015, p.71), the advantages of behavioristic learning theory are as follows: (1) Accustom teachers to be observant and sensitive to learning situations and conditions; (2) The teacher does not give many lectures so that students are accustomed to learning independently, except when students have difficulty having a teacher provide guidance and direction; (3) When a student can form a behavior as desired. Then, he will get positive affirmations, and vice versa; (4) The existence of repetition and continuous training can optimize the talents and intelligence of students; (5) Subject materials that are arranged hierarchically from simple to complex are capable of producing a consistent behavior towards certain fields. 
Implementation of Behaviorism Theory-based Training Learning Model in Physical Education in Class VII Junior High School

Football Game Materials

Pinton Setya Mustafa

pintonsetyamustafa@uinmataram.ac.id

Besides, according to Restian (2015, p.125), the weaknesses of behaviorism learning theory include the following: (1) The process can be observed directly, whereas learning is a process of mental activity that cannot be witnessed from outside except for some of the symptoms; (2) The learning process is automatic-mechanical, so it seems like machines and robots, even though every student has self-direction and cognitive selfcontrol, and because of that he can refuse to respond if he doesn't want to, for example, because they are tired or against their heart; (3) The human learning process analogous to animal behavior is very difficult to accept, given the striking differences in physical and psychological characteristics between humans and animals.

\section{Learning Methods, Models and Strategies Learning}

Methods are steps or learning procedures, including assessment, in the learning plan so that learning objectives are achieved (Suyono \& Hariyanto, 2012, p.22). Furthermore, according to Munir (2012, p.99), learning methods are ways that can be used to implement learning strategies. The learning method can be interpreted as a method used to implement plans that have been prepared in the form of real and practical activities to achieve learning objectives (Nurdin \& Adriantoni, 2016, p.180). The method can be defined as a method or procedure that is taken by the teacher to achieve learning goals (Suyadi, 2013, p.15). The learning method is a method that contains standard procedures for carrying out educational activities (Syah, 2014, p.198).

A learning model is a comprehensive approach to teaching that usually derives from educational theory and includes key assumptions about what students should learn and how they learn (Duke, 2005, p.24). Models are instructional strategies that are designed to achieve specific instructional goals which include planning, implementation, and evaluation stages (Eggen, Kauchack, \& Harder, 1979, p.12; Pham, 2011, p.406). The learning model is a model chosen in the learning plan to achieve learning objectives and implemented with a specific syntax (systematic and sequential steps) (Suyono \& Hariyanto, 2012, p.23). According to Sukmadinata \& Syaodih (2012, p.151), the learning model is a design that describes the detailed process and the creation of environmental situations that allow students to interact so that changes or developments occur in students. A learning model is a form of interaction created between teachers and students related to the strategies, approaches, methods, and learning techniques used in the learning process (Nurdin \& Adriantoni, 2016, p.181). The learning model is a small 
Implementation of Behaviorism Theory-based Training Learning Model in Physical Education in Class VII Junior High School

Football Game Materials

Pinton Setya Mustafa

pintonsetyamustafa@uinmataram.ac.id

description of the overall learning concept including objectives, syntax, environment, and management systems (Suyadi, 2013, p.14). Learning models are guidelines for planning and implementing and evaluating learning that are engineered in such a way as to achieve certain goals (Syah, 2014, p.186).

According to Rusman (2013, p.145) the learning model has the following characteristics: (1) Based on educational theory and learning theory from certain experts; (2) Has a specific educational mission or objectives; (3) Can be used as a guide for improving teaching and learning activities in the classroom; (4) Has parts of the model called: (a) sequence of learning steps (syntax); (b) existence of reaction principles; (c) social system; and (d) support systems; (5) Has an impact as a result of applied learning models; (6) Making teaching preparation (instructional design) with the learning model guidelines he chooses.

According to Gerlach \& Ely (2003, p.174), a learning strategy is a plan to achieve learning objectives consisting of methods and techniques (or procedures) that ensure that learners achieve goals. The learning strategy is a series of activities related to student management, learning management, learning resource management, and assessment to achieve learning objectives (Suyono \& Hariyanto, 2012, p.23). According to Munir (2012, p.99), a learning strategy is a plan made by educators to carry out learning in achieving something with clear indicators. Furthermore, the learning strategy can be interpreted as planning which contains a series of activities designed to achieve certain educational goals (Ahmadi, Amri, \& Elisah, 2011, p.10). The learning strategy is a learning activity that must be done by teachers and students so that learning objectives can be achieved effectively and efficiently (Nurdin \& Adriantoni, 2016, p.180). Meanwhile, according to Suyadi (2013, p.14), Learning strategies are steps taken by the teacher to utilize existing learning resources to achieve learning objectives effectively and efficiently. There are two views of learning strategies, namely learning strategies at the learning planning stage and strategies at the learning implementation stage (Rohani, 2004, p.35; Staddon, 2014, p.17). Learning strategy is several steps that are engineered in such a way as to achieve certain goals (Shah, 2014, p.211). The learning strategy is a general pattern of interaction plans between students and teachers and other learning resources in a learning environment to achieve certain educational goals (MKDP Curriculum and Learning Development Team, 2012, p.195). 
Implementation of Behaviorism Theory-based Training Learning Model in Physical Education in Class VII Junior High School

Football Game Materials

Pinton Setya Mustafa

pintonsetyamustafa@uinmataram.ac.id

Thus it can be concluded that the learning strategy is conceptual in the form of a predetermined learning plan to carry out the learning process. Meanwhile, the learning model is a specific learning design that includes planning, implementation, and evaluation to achieve certain goals. Learning methods are methods or procedures used to achieve learning objectives. So the essence of strategies, models, and methods in learning is the teacher's efforts to design and implement learning to achieve predetermined goals.

\section{Purpose, Function, Usefulness of Learning Models, Methods and Strategies}

The learning model aims to help students obtain information, ideas, skills, values, ways of thinking, and ways to express themselves, teaching them how to learn (Joyce, Weil, \& Calhoun, 2015, p. 6). The learning model aims to streamline the achievement of learning objectives. The success of the learning process is through the application of the learning model used following the conditions of students (Nurdin \& Adriantoni, 2016, p.181). According to Suyadi (2013, pp.14-15), each learning model aims to help students in such a way that learning objectives can be achieved effectively and efficiently, besides being useful as a guide in lesson planning. The learning model serves to overcome problems in learning, overcome the difficulties of teachers in carrying out teaching assignments, and the difficulties of students in learning (Sagala, 2009, p.40). The learning model is useful for shaping curriculum (long-term learning plans), designing learning materials, and guiding learning in class or otherwise (Rusman, 2013, pp.144-145). According to Sukmadinata \& Syaodih, $(2012$, p.151) a learning model can provide several benefits, namely: (1) providing guidelines for teachers and students on how to achieve learning objectives, (2) assisting in curriculum development for classrooms and other subjects, (3) helping in selecting media and sources, (4) helping to increase the effectiveness of learning.

The purpose of the learning method is to activate students and place students as learning subjects (Sukmadinata \& Syaodih, 2012, p.167). The function of the learning method as one of the determinants of success in learning takes place (Ahmadi et al., 2011, p.21). The use of learning methods also determines the effectiveness and efficiency in achieving learning objectives and increasing student activity and creativity (Mulyasa, 2015, p.107). Besides, learning methods are useful in carrying out varied learning activities in terms of learning interactions with students and class sizes (Pribadi, 2011, p.81). 
Implementation of Behaviorism Theory-based Training Learning Model in Physical Education in Class VII Junior High School

Football Game Materials

Pinton Setya Mustafa

pintonsetyamustafa@uinmataram.ac.id

The learning strategy aims to create a good relationship between education and students (Dimyati, 2016, p.3). According to Gerlach \& Ely (2003, p.174), The learning strategy functions to determine the most efficient and effective classroom procedures to achieve predetermined goals. Besides, the learning strategy functions as a strategy so that the presentation of learning becomes systematic by paying attention to the stages/ sequences (Supriadie \& Darmawan, 2012, p.127) Learning strategies are useful for obtaining success or success in achieving certain goals (Ahmadi et al., 2011, p.10).

Thus it can be concluded that the objectives, functions, and uses of learning models, methods, and strategies are to achieve learning objectives effectively and efficiently. Effective means that the expected target is achieved. While efficient means that it requires a relatively short time to achieve the goal or is not wasteful of time in learning carried out by students. The learning model can also aim for teacher guidelines and lesson planning in the classroom. While the learning method can also aim to create an interactive classroom atmosphere between teachers and students. Then the learning strategy also aims to maintain good relations between teachers and students.

\section{Application of Exercise Models in Physical Education Learning Concept of Exercise Learning Model}

Exercise is the repetition of a procedure. Exercise technique is a way of teaching learners by performing a procedure or skill repeatedly (Gagné, Wager, Golas, \& Keller, 2005 , p. 269). Repetition in learning activities is intended for students to understand more deeply (Shoimin, 2014, p.29). Practical exercises, easy to do, and regularly carry out foster children in increasing their mastery of these skills, maybe even learners can have these skills perfectly (Roestiyah, 2008, p.125). Exercise is a way of teaching students to develop proficiency and skills, and can also develop attitudes and habits (Sahabuddin, 2020, p.110; Supriadie \& Darmawan, 2012, p.149). According to Smaldino, Lowther, \& Russell (2014, p.33), the purpose of practice and practice is so that students can master or learn information without errors in mastering knowledge and skills. Students are expected to master a certain skill if they do continuous training which is then provided with feedback and reinforcement, both positive and negative (Munir, 2012, p.69). According to Syah (2014, p.210) based on the law of exercise, the more often a behavior is trained or used, the more stable the existence of the behavior will be. In learning motor skills, it is necessary to provide good training and feedback (Magill \& Anderson, 2016, 
Implementation of Behaviorism Theory-based Training Learning Model in Physical Education in Class VII Junior High School

Football Game Materials

Pinton Setya Mustafa

pintonsetyamustafa@uinmataram.ac.id

p.92; Stones, 1979, p.238).

Thus it can be explained that the training learning model is teaching students by giving it continuous repetition of the material being taught to gain mastery of competencies. This learning exercise includes the development of behaviorism learning theory, namely the learning process that occurs because of a stimulus and response to obtain the desired abilities. The stimulus given by the teacher can make students respond to practice about the material being studied. In the training model suitable for learning skills. PESH is one of the subjects that contains more movement displays.

\section{Exercise Learning Model Procedure}

According to Supriadie \& Darmawan (2012, p.149), preparing the provision of training includes (1) designing training assignments according to competencies and learning outcome indicators, (2) subject matter, (3) steps and stages of training activities, (4) time used, (5) the learning resources used, (6) as well as a clear report format of the training stages.

According to Syah (2014, p.210) several main principles need to be considered by teachers in implementing training models, namely as follows: (1) The exercise must always be preceded or interspersed with the teacher's explanation of the rationale and the importance contained in the skills being trained; (2) The exercise does not bore students, therefore a short time allocation is better; (3) The exercise must attract students 'attention and interest and foster students' motives to think because a student always thinks as long as he does.

According to Supriadie \& Darmawan (2012, p.149) implementing an exercise learning model consisting of (1) Explaining the subject matter of the exercise, indicators of learning outcomes, and basic competencies to be achieved, explaining the stages of learning activities that must be carried out, informing the duration of time required used, inform the learning resources that can be used; (2) Carry out the exercises (individually/in groups) according to the previously prepared design; (3) Supervise and guide them and provide opportunities for question and answer, collect the results of their training as a form of responsibility for carrying out tasks. And at the same time as material to provide an assessment; (4) End the activity by responding or responding to the task at hand, then draw conclusions, and follow up.

According to Roestiyah $(2008, \mathrm{p}$.127) explaining the steps of the training learning 
Implementation of Behaviorism Theory-based Training Learning Model in Physical Education in Class VII Junior High School

Football Game Materials

Pinton Setya Mustafa

pintonsetyamustafa@uinmataram.ac.id

model are as follows: (1) Use this exercise only for learning subjects that are carried out automatically, without using deep thought and consideration. But it can be done quickly like a reflex; (2) Teachers must choose exercises that have a broad meaning that can instill an understanding of the meaning and purpose of the exercises before they do. So that training can rely on students for the usefulness of their present or future lives; (3) The teacher must emphasize the diagnosis because the initial training cannot expect students to acquire perfect skills. In the next exercise, the teacher examines the obstacles that arise and are experienced by students, so that they can choose or determine which exercises need to be improved; (4) It is necessary to prioritize accuracy, and pay attention to speed so that students perform speed and skill according to predetermined time; (5) The teacher pays attention to the time during the practice so that it is not too long and not too short, because if it is too long it will be boring. The training period should be fun and interesting, giving rise to optimism and a sense of joy which can lead to good skill; (6) Teachers and students prioritize essential/essential processes and are not involved in things that are not needed; (7) Teachers need to pay attention to individual student differences so that the abilities and needs of each student can develop; (8) Teachers and students conclude from the results of the exercise.

Furthermore, according to Majid (2014, p. 214) the steps in implementing the training learning model are as follows: (1) Students must be given a deep understanding before certain exercises are held; (2) The exercise for the first time should be diagnostic. If it is not successful, then improvements are made to make it more perfect; (3) The exercise does not need to belong as long as it is often carried out; (4) Must be adapted to the level of ability of students; (5) The training process should prioritize things that are essential and useful.

Thus it can be concluded that the procedure for the training learning model consists of the preparation stage, the implementation stage, and the evaluation stage. In the preparation stage, namely: (1) the teacher formulates the objectives and learning materials, (2) the teacher prepares the exercise design that is given to the students, (3) the teacher determines the duration of each exercise pattern, (4) the teacher designs an assessment of the student's training results. At the implementation stage, it consists of: (1) the teacher explains the learning material, (2) the teacher explains the training patterns to be carried out by the students, (3) the teacher instructs the students to do the training 
Implementation of Behaviorism Theory-based Training Learning Model in Physical Education in Class VII Junior High School

Football Game Materials

Pinton Setya Mustafa

pintonsetyamustafa@uinmataram.ac.id

patterns that have been designed, (4) during the exercise takes place the teacher provides an interlude of feedback, (5) the teacher and students conclude the essence of the exercise. Then at the evaluation stage, namely: (1), the teacher assesses the results of the student's ability from the learning, (2) the teacher makes a reflection of the training learning model.

\section{Strengths and Weaknesses of the Exercise Learning Model}

As a learning model, of course, it also has several advantages and disadvantages. According to Djamarah \& Zain (2010, p.96), the strengths and weaknesses of the exercise learning model are as follows. The advantages of the training learning model are: (1) To seek intelligence or motor skills, such as writing, pronouncing letters, words, games, and athletics); (2) To acquire mental skills such as in multiplying, adding up, dividing signs or symbols and so on; (3) To acquire skills in the form of associations, which are made such as the relationship of letters in spelling, using symbols, reading maps and so on; (4) Forming habits that are carried out and increasing the determination and speed of implementation; (5) The formation of habits makes complex, complex movements more automatic. While the weaknesses of the training learning model are: (1) Inhibiting the talents and initiative of students, because more students are brought into adjustment and directed far from understanding; (2) Causing static adjustment to the environment; (3) Sometimes repeated exercises are monotonous; (4) Can lead to verbalism.

According to Smaldino et al. (2014, p.33), Exercise and practice have advantages and disadvantages. The advantages include: (1) Students get feedback as a corrective action for their responses; (2) Information is presented in small pieces, which provide opportunities for students to review lesson materials in small pieces; (3) Provide opportunities for students to immediately try new knowledge through positive ways. While the limitations of the exercise learning model include: (1) Not all students respond well to the repetitive nature of training and practice; (2) Students may become bored with too many repetitions; (3) If a student makes the same mistake, applying practice material and practice does not help the student in learning.

Thus it can be concluded that the training learning model tends to be more successful to be applied in the aspects of skills and abilities of students. Meanwhile, weaknesses in the training learning model tend to hinder students' critical thinking, because students only do the teacher's orders and memorize the exercise patterns. 
Implementation of Behaviorism Theory-based Training Learning Model in Physical Education in Class VII Junior High School

Football Game Materials

Pinton Setya Mustafa

pintonsetyamustafa@uinmataram.ac.id

\section{Exercise Learning Model in PESH Class VII SMP}

In learning PESH which emphasizes the practice of movement skills, training models can be used. The characteristics of the self-training learning model in PESH called the practice style or training style with the defining characteristics of the training style are individual and personal training of the memory/feedback reproduction task (Mosston \& Ashworth, 2008, p.94). The role of practice is very important, namely to help build relationships or arrange stimuli and responses and as a means to build associations between concepts and propositions in memory (Schunk, 2012, p.20). Its general practice style has been proven to be reliable and effective in facilitating learning that involves remembering facts, generalizing (defining and illustrating concepts), association (applying explanations), and stringing (automatically performing prescribed procedures) (Ertmer \& Newby, 2013, p.43).

Anatomical training model according to Mosston \& Ashworth (2008, p.96), namely: Pre-impact is done by the teacher; Impact is carried out by students, and PostImpact carried out by the teacher. The teacher's role includes: (1) being willing to answer students' questions, (2) gathering information about student performance, and offering personal feedback. Meanwhile, the students' roles are: (1) to perform tasks, (2) make nine decisions (task sequence, start time, speed and rhythm, stopping time, interval, location, posture, clothing and appearance, questions for clarification) (Mosston \& Ashworth, 2008, p.100) The steps with behaviorism learning theory with a training model can make the implementation of curriculum content simpler and more manageable which can then be repeated by monitoring continuous student learning (Weegar, MA, \& Pacis, 2012, p.18). In learning motor skills, exercise teaching styles can contribute to improving students' mobility (Proios, 2018, p. 1, 2019, p.77; Sahabuddin \& Bismar, 2020, p.51).

PESH as a field of practice has the potential to achieve the various educational outcomes needed to support its selection and application in determining movement variations in motion training (Kirk, 2013, p.973). In learning PESH, teachers can introduce elements of movement skills in a short command style, then students train motor skills on their own and are involved in giving and receiving feedback and analyzing the performance of motor skills (Goldberger, Ashworth, \& Byra, 2012, p.275). The training style is proven to be effective in promoting motor skills in students, but teachers need to provide feedback when the PESH learning process takes place to 
Implementation of Behaviorism Theory-based Training Learning Model in Physical Education in Class VII Junior High School

Football Game Materials

Pinton Setya Mustafa

pintonsetyamustafa@uinmataram.ac.id

improve students' cognitive and social abilities (Aktop \& Karahan, 2012, p.1913; C. Chatoupis \& Vagenas, 2018, p.189). The style of teaching exercises carried out by sports teachers can improve metacognitive skills, lesson satisfaction, and intrinsic motivation in students (Chatzipanteli, Digelidis, \& Papaioannou, 2015, p.333). The results of the research show that learning with the delivery of effective instruction, corrective feedback, and structured opportunities to practice facilitates the achievement of students with more complex and higher results in movement skills (Creasy, Whipp, \& Jackson, 2012, p.10). The training model is carried out by the teacher when learning PESH by giving motion tasks to students with the provisions of the learning objectives to be achieved (Chatoupis \& Vagenas, 2017, p.220; Sahabuddin \& Hakim, 2020, p.41). Thus in doing the training model in PESH, the teacher must design skills models that students must practice. Furthermore, an example will be given of the implementation of the PESH learning steps for the training model in class VII SMP with Basic Competencies 3.1 and 4.1 in the 2013 Curriculum in Table 2 below:

Table 2.

Steps for Learning PESH ( 3 hours of study or $3 \times 40$ minutes $=120$ minutes)

Activities
(1) The teacher lines the students into 4 steps
(2) The teacher leads the prayer followed by attendance.
(3) The teacher ensures that all students are in good health
and orders them to clean up trash in the field.
(4) The teacher asks students about the concept of playing
football in general, provokes students to tell their
experience of playing football.
(5) The teacher conveys the scope of the material to be
studied, namely: (1) basic principles of kicking a ball,
(2) basic principles of holding, (3) basic principles of
dribbling 10
(6) The teacher explains the competencies that students
must achieve after the learning process (as stated in the
competency achievement indicators) accompanied by
an explanation of the benefits of playing football
activities
(7) The teacher explains the assessment techniques for
football competence including knowledge and skills.


(1) Observe Students carry out the first activity by observing the principle of kicking a ball using the inner foot, stopping the ball rolling on the ground with the inner foot, dribbling with the inner foot provided and carried out by the teacher and/or students, then recording things which are not yet known related to the position of the hands, arms, feet, knees, heels, eyesight, the direction of the ball

(2) Asking Students formulate questions related to things they don't / want to know about the basic techniques of football that are observed,

The teacher leads the warm-up before starting the practice of learning football

(4) Exploring $\bullet$ Students are divided into 5 groups consisting of \pm 6 people, each group is given 1 ball.

a) Each group is divided into 2 parts facing each other to perform the basic techniques of soccer kicking and stopping the ball alternately

Core

b) Each student performs the basic techniques of soccer dribbling and stopping the ball alternately

c) The teacher provides feedback during the activity

(5) Associating

a) Learning activities of variations of the basic techniques of kicking and stopping the ball by (1) a triangle formation and (2) the ball is directed to the target of a friend in turn

b) Learning activities on various basic dribbling techniques by (1) circling the cone and (2) zig-zag.

c) During the activity, students receive feedback individually and classically from the teacher.

(6) Communicating

a) Students try specific motion tasks for soccer games into simple games based on the values of discipline, confidence, sportsmanship, and cooperation which include: (1) dribbling competitions and (2) small side games for 3-5 players

b) During the activity, students receive feedback individually and classically from the teacher.

(1) The teacher leads the cooling after the students practice.

(2) Teachers and students make conclusions from all material.

Closing

(3) Teachers and students reflect on what has been achieved and what has not been achieved following the objectives set.

(4) The teacher provides a follow-up and explains the 

material for the next meeting.

(5) The teacher gives assignments related to today's learning and future lessons.

(6) Teachers lead prayers according to their respective religions and beliefs.

(7) Students return to the class which is carried out in an orderly manner, for students who are on duty, return the equipment to its original place.

\section{CONCLUSIONS AND SUGGESTIONS}

Learning is a process of changing behavior (cognitive, affective, psychomotor) which is relatively permanent as a result of training and experiences. Learning is an effort to teach students to achieve the expected results. In learning theory, behaviorism learning occurs as a result of stimuli and responses. A stimulus is something that is given by the teacher to stimulate students to learn, while the response is a response from the teacher's stimulus to learn. In achieving the effectiveness and efficiency of learning, learning strategies, methods and models are needed. Learning strategy is general planning to achieve learning goals. Learning methods are methods and procedures that are carried out to achieve learning objectives. Then the model is a more specific and comprehensive guideline for achieving learning objectives. One of the behaviorism learning models is exercise. The training model in learning is repeating the material given by the teacher with the aim that students can master the material. The training model is suitable for use in skills. One of the subjects with a dominant portion of movement skills in Physical Education, Sports, and Health (PESH). PESH is part of education with the characteristic of teaching students through physical movement activities to achieve competency goals. The content of PESH material leads to skills, one of which is the basic techniques of playing in sports. So with the characteristics of PESH lessons like this, the training model is suitable for use in learning that focuses on movement skills. In implementing the exercises, it is necessary to pay attention to the exercise design, duration, and feedback for students. This is done so that the learning objectives are achieved. However, the training model also has a weakness, which prevents students from thinking critically and creatively, because all training designs are only provided by the teacher. 


\section{REFERENCES}

Ahmadi, I. K., Amri, S., \& Elisah, T. (2011). Strategi Pembelajaran Sekolah Terpadu. Jakarta: Prestasi Pustaka.

Aktop, A., \& Karahan, N. (2012). Physical Education Teacher's Views of Effective Teaching Methods in Physical Education. Procedia - Social and Behavioral Sciences, 46(2003), 1910-1913.

Budiningsih, C. A. (2005). Belajar dan Pembelajaran. Jakarta: Rineka Cipta.

Chatoupis, C. C., \& Vagenas, G. (2017). Effects of Two Practice Style Formats on Fifth Grade Students' Motor Skill Performance and Task Engagement. The Physical Educator, 74(2), 220-238.

Chatoupis, C., \& Vagenas, G. (2018). Effectiveness of the Practice Style and Reciprocal Style of Teaching: A Meta-Analysis. The Physical Educator, 75(2), 175-194.

Chatzipanteli, A., Digelidis, N., \& Papaioannou, A. G. (2015). Self-Regulation, Motivation and Teaching Styles in Physical Education Classes: An Intervention Study. Journal of Teaching in Physical Education, 34(2), 333-344.

Creasy, J., Whipp, P., \& Jackson, B. (2012). Teachers' Pedagogical Content Knowledge and Students' Learning Outcomes in Ball Game Instruction. ICHPER-SD Journal of Research, 7(1), 3-11.

Desmita. (2009). Psikologi Perkembangan Peserta Didik. Bandung: Remaja Rosdakarya.

Dimyati, J. (2016). Pembelajaran Terpadu Untuk Taman Kanak-Kanak/ Raudatul Atfal Dan Sekolah Dasar. Jakarta: Kencana.

DiVesta, F. J., \& Thompson, G. G. (1979). Educational Psychology: Introduction and Behaviour Change. New York: Meredith.

Djamarah, S. B., \& Zain, A. (2010). Strategi Belajar Mengajar. Jakarta: Rineka Cipta.

Duke, D. L. (2005). Education Empire: The Evolution of an Excellent Suburban School System (SUNY Series, Educational Leadership). New York: State University of New York Press.

Eggen, P. D., Kauchack, D. P., \& Harder, R. J. (1979). Strategies for Teachers: Information Processing Models in The Classroom. Englewood Cliffs: Prentice-Hall.

Ertmer, P. A., \& Newby, T. J. (2013). Behaviorism, Cognitivism, Constructivism: Comparing Critical Features From an Instructional Design Perspective. Performance Improvement Quarterly, 26(2), 43-71.

Gagné, R. M., Wager, W. W., Golas, K. C., \& Keller, J. M. (2005). Principles of Instructional Design (5th ed.). United States: Wadsworth, Cengage Learning.

Gerlach, V. S., \& Ely, D. P. (2003). Teaching and Media: A Systematic Approach. (S. Grabowski, Ed.) (2nd ed.). Englewood Cliffs: Prentice-Hall. 
Goldberger, M., Ashworth, S., \& Byra, M. (2012). Spectrum of Teaching Styles Retrospective 2012. Quest, 64(4), 268-282.

Haris, A., \& Jihad, A. (2010). Evaluasi Pembelajaran. Yogyakarta: Multi Pressindo.

Hitipeuw, I. (2009). Belajar \& Pembelajaran. Malang: FIP UM.

Joyce, B., Weil, M., \& Calhoun, E. (2015). Models of Teaching (9th ed.). Boston: Pearson.

Kirk, D. (2013). Educational Value and Models-Based Practice in Physical Education. Educational Philosophy and Theory, 45(9), 973-986.

Magdalena, I., Hidayah, A., \& Astuti, A. W. (2020). Peran Kinerja Guru dalam Meningkatkan Prestasi Belajar Siswa Sekolah Dasar. Nusantara: Jurnal Pendidikan dan Ilmu Sosial, 2(3), 383-392.

Magill, R., \& Anderson, D. I. (2016). Motor Learning and Control: Concepts and Applications (11th ed.). Dubuque: McGraw-Hill Education.

Majid, A. (2014). Strategi Pembelajaran. Bandung: Remaja Rosdakarya.

Mosston, M., \& Ashworth, S. (2008). Teaching Physical Education: First on-line edition.

Mulyasa, E. (2015). Menjadi Guru Profesional: Menciptakan Pembelajaran Kreatif dan Menyenangkan. Bandung: Remaja Rosdakarya.

Munir. (2012). Multimedia Konsep \& Aplikasi dalam Pendidikan. Bandung: Alfabeta.

Mustafa, P. S., \& Dwiyogo, W. D. (2020). Kurikulum Pendidikan Jasmani, Olahraga, dan Kesehatan di Indonesia Abad 21. Jurnal Riset Teknologi dan Inovasi Pendidikan (JARTIKA), 3(2), 422-438.

Mustafa, P. S., \& Sugiharto. (2020). Keterampilan Motorik pada Pendidikan Jasmani Meningkatkan Pembelajaran Gerak Seumur Hidup. Jurnal Sporta Saintika, 5(2), 199-218.

Mustafa, P. S., \& Winarno, M. E. (2020). Penerapan Pendekatan Saintifik dalam Aktivitas Belajar Pendidikan Jasmani, Olahraga, dan Kesehatan di SMK Negeri 4 Malang. Jurnal Penjakora, 7(2), 78-92.

Mustafa, P. S., Winarno, M. E., \& Asim. (2016). Pengembangan Variasi Latihan Service Atas untuk Peserta Ekstrakurikuler Bolavoli di SMK Negeri 4 Malang. Jurnal Pendidikan Jasmani, 26(1), 159-175.

Mustafa, P. S., Winarno, M. E., \& Supriyadi. (2019). Penilaian Pendidikan Jasmani, Olahraga, dan Kesehatan pada Sekolah Menengah Pertama Negeri Kota Malang. Jurnal Pendidikan: Teori, Penelitian, dan Pengembangan, 4(10), 1364-1379.

Nurdin, S., \& Adriantoni. (2016). Kurikulum dan Pembelajaran. Jakarta: Raja Grafindo Persada. 
Peraturan Pemerintah Republik Indonesia Nomor 19 Tahun 2005 tentang Standar Nasional Pendidikan. (2005).

Permendikbud. (2016). Peraturan Menteri Pendidikan dan Kebudayaan Republik Indonesia Nomor 24 Tahun 2016 tentang Kompetensi Inti dan Kompetensi Dasar Pelajaran pada Kurikulum 2013 pada Pendidikan Dasar dan Pendidikan Menengah.

Pham, H. (2011). Theory-Based Instructional Models Applied in Classroom Contexts. Literacy Information and Computer Education Journal (LICEJ), 2(2), 406-415.

Pribadi, B. A. (2011). Model Assure untuk Mendesain Pembelajaran Sukses. Jakarta: Dian Rakyat.

Proios, M. (2018). Implications of The Practice Style Teaching on Motor and Knowledge Performance of A Basic Gymnastics Skill. European Journal of Physical Education and Sport Science, 5(1), 1-18.

Proios, M. (2019). Effects of practice style on a complex gymnastics skill performance of high-, medium-, and low-skilled learners. Science of Gymnastics Journal, 11(1), 77-90.

Restian, A. (2015). Psikologi Pendidikan Teori \& Aplikasi. Malang: UMM. Press.

Richey, R. C., Klein, J. D., \& Tracey, M. W. (2011). The Instructional Design Knowledge Base: Theory, Research, and Practice. New York: Routledge Taylor \& Francis.

Roesdiyanto. (2017). Kompetensi Profesional Guru Pendidikan Jasmani, Olahraga dan Kesehatan (Dalam Kompetensi Inti Pemahaman Tujuan Pembelajaran dan Memilih Materi Pembelajaran Sesuai dengan Tingkat Perkembangan Peserta Didik). Artikel dipublikasikan dalam Prosiding. Seminar Nasional Profesionalisme Tenaga Profesi Pendidikan Jasmani, Olahraga, dan Kesehatan (pp. 624-630). Malang: Jurusan Pendidikan Olahraga Pascasarjana UM.

Roestiyah, N. K. (2008). Strategi Belajar Mengajar. Jakarta: Rineka Cipta.

Rohani, A. (2004). Pengelolaan Pengajaran. Jakarta: Erlangga.

Rusman. (2013). Model-Model Pembelajaran. Jakarta: RajaGrafindo Persada.

Sagala, S. (2009). Konsep dan Makna Pembelajaran Untuk Membantu Memecahkan Problematika Belajar dan Mengajar. Bandung: Alfabeta.

Sahabuddin, \& Hakim, H. (2020). Penerapan Latihan Model Dhin Dhon pada Klub Bolavoli di Kabupaten Bantaeng. Celebes Abdimas: Jurnal Pengabdian Kepada Masyarakat, 2(1), 32-42.

Sahabuddin, S. (2020). Pengaruh Latihan Smash Bola Gantung dan Bola Lambung Terhadap Kemampuan Smash Dalam Permainan Sepaktakraw. SPORTIVE: Journal Of Physical Education, Sport and Recreation, 3(2), 105-111.

Sahabuddin, S., \& Bismar, A. R. (2020). Pengaruh Latihan Akselerasi Terhadap Kemampuan Lari 50 Meter. Jurnal Speed (Sport, Physical Education, Empowerment), $3(1), 51-57$. 
Santrock, J. W. (2012). Psikologi Pendidikan: Educational Psychology Buku 1. Jakarta: Salemba Humanika.

Schunk, D. H. (2012). Learning Theories: An Educational Perspective (6th ed.). Boston: Pearson.

Shimon, J. M. (2011). Introduction to Teaching Physical Education: Principles and Strategies. United States: Human Kinetics.

Shoimin, A. (2014). 68 Model Pembelajaran Inovatif dalam Kurikulum 2013. Yogyakarta: ArRuzz Media.

Siedentop, D., Hastie, P. A., \& Mars, H. van der. (2011). Complete Guide to Sport Education (2nd ed.). United States: Human Kinetics.

Smaldino, S. E., Lowther, D. L., \& Russell, J. D. (2014). Instructional Technology and Media for Learning (10th ed.). London: Pearson Education Limited.

Staddon, J. (2014). The New Behaviorism (2nd ed.). New York: Psychology Press.

Stones, E. (1979). Psychopedagogy: Psychological Theory and The Practice of Teaching. London: Methuen.

Sudjana, N. (2010). Dasar-Dasar Proses Belajar Mengajar. Bandung: Sinar Baru Algesindo.

Sukmadinata, N. S., \& Syaodih, E. (2012). Kurikulum dan Pembelajaran Kompetensi. Bandung: Refika Aditama.

Supriadie, D., \& Darmawan, D. (2012). Komunikasi Pembelajaran. Bandung: Remaja Rosdakarya.

Suyadi. (2013). Strategi Pembelajaran Pendidikan Karakter. Bandung: Remaja Rosdakarya.

Suyono, \& Hariyanto. (2012). Belajar dan Pembelajaran. Bandung: Remaja Rosdakarya.

Syah, M. (2014). Psikologi Pendidikan dengan Pendekatan Baru. Bandung: Remaja Rosdakarya.

Syrmpas, I., \& Digelidis, N. (2014). Physical education student teachers' experiences with and perceptions of teaching styles. Journal of Physical Education and Sport, 14(1), $52-59$.

Thobroni, M. (2015). Belajar \& Pembelajaran: Teori dan Praktik. Yogyakarta: Ar-Ruzz Media.

Tim Pengembang MKDP Kurikulum dan Pembelajaran. (2012). Kurikulum \& Pembelajaran. Jakarta: Rajawali Pers.

Weegar, M. A., \& Pacis, D. (2012). A Comparison of Two Theories of Learning Behaviorism and Constructivism as applied to Face-to-Face and Online Learning. E-Leader Conference. Manila. 